\title{
Expression of glucocorticoid receptor mRNAs in glucocorticoid-resistant nasal polyps
}

\author{
Bo-Ra Choi ${ }^{1 *}$, Jae-Hwan Kwon ${ }^{2 *}$, \\ Soo-Jung Gong ${ }^{1}$, Min-Sang Kwon ${ }^{2}$, \\ Joong-Hwan $\mathrm{Cho}^{2}$, Jae Hyun $\mathrm{Kim}^{3}$, \\ Sangtaek $\mathrm{Oh}^{4}$, Hwan-Jung $\mathrm{Roh}^{5}$ and \\ Dong-Eun Kim ${ }^{1,6}$
}

${ }^{1}$ Departments of Biotechnology and Bioengineering, and Biomaterial Control

Dong-Eui University

Busan 614-714, Korea

${ }^{2}$ Department of Otorhinolaryngology-Head and Neck Surgery

Maryknoll General Hospital

Busan 600-730, Korea

${ }^{3}$ Nambu Blood Laboratory, Korean Red Cross

Busan 614-814, Korea

${ }^{4}$ PharmcoGenomics Research Center

Inje University

Busan 614-735, Korea

${ }^{5}$ Department of Otolaryngology

College of Medicine, Pusan National University

Busan 602-739, Korea

${ }^{6}$ Corresponding author: Tel, 82-51-890-2277;

Fax, 82-51-890-1619; E-mail, kimde@deu.ac.kr

*These authors contributed equally to this work.

Accepted 15 June 2006

Abbreviations: GC, glucocorticoid; hGR, human glucocorticoid receptor; hGR $\beta$, human glucocorticoid receptor isoform $\beta$

\begin{abstract}
Glucocorticoids (GCs) are the most effective group of medications available to treat inflammation. Although most patients with inflammation respond to GC, a small group of patients exhibit persistent GC-resistance with prolonged inflammation. Previously, it was proposed that the GC-resistance is caused by low amount of human GC receptor ( $h G R \alpha)$ and/or excessive presence of a GC receptor isoform, $h G R \beta$ that was generated from alternative splicing of the hGR message. We have tested this hypothesis by investigating correlation between the expression pattern of hGR mRNAs in patients with inflammatory nasal polyps and the effectiveness of GC treatment. We have performed reverse transcription PCR analysis of mRNAs coding each $h G R \alpha$ and $h G R \beta$ in
\end{abstract}

nasal tissues. hGR $\alpha$ mRNA was more expressed in patients with nasal polyps than in normal subjects. However, the elevated hGR $\alpha$ mRNA expression was decreased after GC treatment. Compared with hGR $\alpha$ mRNA expression, level of $h G R \beta$ mRNA expression was very low in all groups. In patients, hGR $\beta$ mRNA was expressed at a similar level regardless of GC efficacy, indicating that there is no correlation between the GC sensitivity and the expression level of hGR $\beta$ mRNA. Thus, persistent GC-resistance is not associated with low expression of hGR $\alpha$ or overexpression of hGR $\beta$.

Keywords: drug resistance; glucocorticoid; glucocorticoid receptors; nasal polyps; reverse transcriptase polymerase chain reaction

\section{Introduction}

Tissue inflammation and immune activation play an important role in the pathogenesis of chronic allergic diseases (Oettgen et al., 2001; Ruiz-Irastorza et al., 2001; Wills-Karp et al., 2001). Glucocorticoids (GC) are one of the most potent medications in the treatment of inflammation caused by allergy and autoimmune disorder. Although most patients with allergic diseases respond to $\mathrm{GC}$ treatment, a small group of patients demonstrate persistent tissue inflammation despite treatment with high doses of GCs (Leung et al., 2003). Since GC resistance complicates the management of these patients, knowledge of the molecular mechanisms responsible for GC insensitivity is critical for the development of effective therapies.

The ability of GC to act on a target tissue and elicit anti-inflammatory effect is mediated by the presence of the $\alpha$ isoform of human GC receptor ( $h G R \alpha$ ) (Cato et al., 1996). hGR $\alpha$ belongs to the superfamily of large steroid-nuclear receptor that also includes receptors for mineralocorticoids, thyroid hormone, retinoic acid, and vitamin D (Oakley et al., 1999). hGR $\alpha$ functions as ligand-dependent transcription factor that regulates expression of several inflammation-related target genes. $h \mathrm{GR} \alpha$ is expressed in almost all tissues and cells, and in the absence of GC it is mainly located in the cytoplasm of cells as part of a large multiprotein complex (Oakley et al., 1999). This complex consists of the 
receptor, two molecules of heat shock protein hsp90, and several additional factors (Pratt et al., 1993; Smith et al., 1993). When GC binds the receptor, the multiprotein complex dissociates, resulting in the release of $h G R \alpha$. hGR $\alpha$ translocates into the nucleus, where it forms homodimer and specifically binds to glucocorticoid-responsive elements (GREs) located in the regulatory regions of target genes. The bound GR homodimer interacts with the basal transcription factors, which subsequently modulates transcription of the target genes.

In addition to hGR $\alpha$, an isoform deficient in GC binding has been isolated in humans and termed hGR $\beta$ (Hollenberg et al., 1985). Human hGR $\alpha$ variant $h G R \beta$ is generated by alternative splicing of the human GR (hGR) gene (Figure 1), and hGR $\beta$ differs from the wild-type receptor ( $h G R \alpha$ ) only at the carboxy terminus (Hollenberg et al., 1985; Encio et al., 1991; Oakley et al., 1996). The two isoforms are identical through amino acid 727 but then diverge, with $\mathrm{hGR} \alpha$ having an additional 50 amino acids and hGR $\beta$ an additional nonhomologous 15 amino acids. It was known that hGR $\beta$ resides in the nucleus of cells independent of GC treatment and does not bind GC. Some groups reported that hGR $\beta$ functions as a dominant inhibitor of $\mathrm{hGR} \alpha$ in transfected cells (Bamberg et al., 1995; Oakley et al., 1996). However, this observation was not reproduced by others
(Bamberger et al., 1997; Hecht et al., 1997; Brogan et al., 1999; de Lange et al., 1999).

From the studies of asthmatic patients treated with $\mathrm{GC}$, it has been proposed that resistance to the anti-inflammatory effects of GC could result from an elevated level of hGR $\beta$ expression (Leung et al., 1997). Glucocorticoid resistance in asthma has also been associated with qualitative or quantitative deficiency in hGR $\alpha$ (Sher et al., 1994). However, it is still controversial about the putative role of hGR $\beta$ as a dominant inhibitor of $\mathrm{hGR} \alpha$ in the GC- treated asthmatic patients (Gagliardo et al., 2000). In contrast to the studies of asthma patients with a respect to hGR gene expression in GC resistance, expression of hGR $\alpha$ and hGR $\beta$ in nasal polyps caused by inflammation and its hypothetical correlation with glucocorticoid-resistance has not yet been investigated.

An immunostaining study shows that hGR $\alpha$ and hGR $\beta$ isoform was mainly present in ephithelial cells and infiltrating inflammatory cells in subepithelial layer of nasal tissues (Kang et al., 2000). The study has suggested that increased number of inflammatory cells infiltrating the nasal mucosa did not amplify the amount of immunostained hGR proteins. Thus, in this study, to evaluate the entire level of hGR messages present in the cells of nasal polyp we have chosen nasal tissues instead of respectively
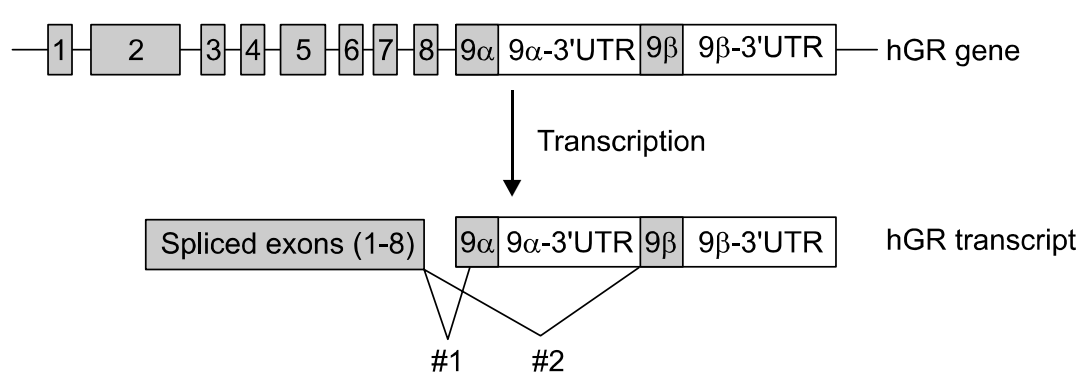

Alternative splicing

hGR $\alpha$ mRNA generated by splicing event \#1 and alternative polyadenylation

\begin{tabular}{|c|c|c|c|c|}
\hline $1-8$ & $9 \alpha$ & $9 \alpha-3$ 'UTR & $9 \beta$ &  \\
\hline $1-8$ & $9 \alpha$ & $9 \alpha-3$ 'UTR & An & \\
\hline
\end{tabular}

RT-PCR product (hGR $\alpha$ cDNA, 478 bp)
hGR $\beta$ mRNA generated by splicing event \#2

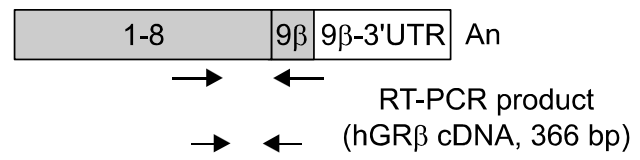

Nested PCR product

(hGR $\beta$ cDNA, 134 bp)

Figure 1. Organization of the hGR gene and gene products. hGR sequences formerly identified as exon 9 were composed of exon $9 \alpha$, and exon $9 \beta$. Alternative splicing event generates multiple $h G R$ messages. The $h G R \alpha-$ and hGR $\beta$ - specific cDNA primers for RT-PCR in this study are indicated solid arrows. Note that RT-PCR product for hGR $\beta$ message was reamplified through a second round of PCR (nested PCR) and CDNA primers for the nested PCR were indicated as solid arrows below the RT-PCR product. UTR and An represents untranslated sequences and polyadenylated tail sequence, respectively. 
cultured cells derived from nasal tissues or peripheral blood mononuclear cells from blood. We analyzed the expression of hGR $\alpha$ and hGR $\beta$ at mRNA level in the tissues derived from patients with nasal polyps as well as from the normal subjects to better understand persistent GC-resistance in nasal polyps and assess whether this inflammatory disease is associated with a dysregulation of hGR $\alpha$ or hGR $\beta$.

\section{Materials and Methods}

\section{Preparation of nasal tissue samples}

Patients with nasal polyps who visited the local hospital (Maryknoll Hospital, Busan, Korea) were selected under a written consent for a participation of this study. They were divided into three patient groups (Table 1). The first patient group (P1) consisted of 21 subjects with nasal polyp who took GC treatment and showed positive efficacy of the medication. The second patient group (P2) consisted of 12 subjects with nasal polyp who showed negative efficacy of the medication with a persistent GC insensitivity, resulting in a required surgical removal of polyp after the GC-treatments for 2 weeks. These patients (P1 and P2) had not been exposed to any GC medication at least for 6 weeks prior to a short course (2 weeks) of oral GC (20 mg/day prednisolone) treatment, and their nasal biopsy specimens were obtained after the medication. Nasal tissues of some patients of group P1 were taken before and after the GC treatment to compare the changes of hGR mRNA expression during the medication. The third patient group (P3) consisted of 21 subjects with nasal polyp who took the operation for a surgical removal of polyp without prior GC treatment. Their nasal tissue specimens were obtained from the removed nasal polyp during the operation. As a control group, nasal tissues from normal subjects were obtained from 10 subjects who underwent maxillofacial surgery after facial trauma. They had not been exposed to the GC treatment and termed as a normal group (group N). Nasal tissues taken from each subject were immediately washed with saline solution and were kept frozen at $-80^{\circ} \mathrm{C}$. The frozen tissue samples were used within a week for RNA isolation.

\section{Isolation and analysis of total RNA}

Total RNA was extracted by lysing 2 to $3 \mathrm{~g}$ of isolated nasal tissues prepared as above. RNA extraction was performed by following a standard protocol. Briefly, the extracted RNA in the aqueous phase was obtained after homogenization of the finely sliced tissues in the reaction mixture containing RNA PrepMate ${ }^{\mathrm{TM}}$ lysis buffer (Bioneer, Daejeon, Korea) and chloroform, followed by centrifugation at $10,000 \mathrm{~g}$ for $10 \mathrm{~min}$ at $4^{\circ} \mathrm{C}$. Supernatant containing RNA was mixed with equal volume of phenol:chloroform $(5: 1)$ mixture and centrifuged at $12,000 \mathrm{~g}$ for $5 \mathrm{~min}$ at $4^{\circ} \mathrm{C}$. The RNA extract was precipitated with 1 volume of isopropanol at $-20^{\circ} \mathrm{C}$ for $10 \mathrm{~min}$ and centrifuged at $10,000 \mathrm{~g}$ for $10 \mathrm{~min}$ at $4^{\circ} \mathrm{C}$. The RNA pellet was washed with $80 \%$ ethanol, vacuum dried briefly, solubilized in water, and stored at $-80^{\circ} \mathrm{C}$ until subsequent analysis. The quantity of RNA was calculated by spectrophotometry at 260 $\mathrm{nm}$. The integrity of purified RNA was determined by visualization of the $28 S$ and $18 S$ ribosomal RNA bands after electrophoresis of 1 to $2 \mu \mathrm{g}$ of each RNA sample through a $1.0 \%$ formaldehyde agarose gel.

\section{Reverse transcription and polymerase chain reaction}

An amount of $1 \mu \mathrm{g}$ of total RNA was subjected to reverse transcription (RT) for $1 \mathrm{~h}$ at $42^{\circ} \mathrm{C}$. Reaction mixture contained $1 \mathrm{mM}$ deoxynucleotide mixture (Roche, Germany), 40 U RNase OUT ${ }^{\mathrm{TM}}$ (Invitrogen), $1.6 \mu \mathrm{g}$ oligo dT (Bioneer, Daejeon, Korea), and $50 \mathrm{U}$ of AMV reverse transcriptase (Roche, Germany) in $20 \mu$ supplied buffer. The reaction mixture was initially incubated at $25^{\circ} \mathrm{C}$ for $10 \mathrm{~min}$ for annealing of primer to the RNA template and was then further incubated for $1 \mathrm{~h}$ at $42^{\circ} \mathrm{C}$ for $\mathrm{RT}$ reaction. The reac-

Table 1. Characteristics of the patients and normal subjects.

\begin{tabular}{|c|c|c|c|c|}
\hline & \multicolumn{2}{|c|}{ GC-treated polyp patients } & \multirow{2}{*}{$\begin{array}{l}\text { GC-untreated } \\
\text { polyp patients }\end{array}$} & \multirow{2}{*}{$\begin{array}{l}\text { Normal } \\
\text { subjects }\end{array}$} \\
\hline & GC-effective & GC-ineffective & & \\
\hline Group name & $\mathrm{P} 1$ & $\mathrm{P} 2$ & P3 & $\mathrm{N}$ \\
\hline Number of cases & 21 & 12 & 21 & 10 \\
\hline Gender (M/F) & $12 / 9$ & $7 / 5$ & $11 / 10$ & $8 / 2$ \\
\hline Age, yr & $44(15-76)$ & $32(17-58)$ & $47(7-65)$ & $35(19-52)$ \\
\hline $\begin{array}{c}\text { Oral prednisolone } \\
\text { (dose, mg/daily) }\end{array}$ & 20 & 20 & 0 & 0 \\
\hline
\end{tabular}


tion mixture was heated to $98^{\circ} \mathrm{C}$ for 5 min to stop RT.

The primers used for amplification of hGR $\alpha$ message were as follows (Figure 1): 5'-CCTAAGGACGGTCTGAAGAGC-3' (upstream) and 5'-GCCAAGTCTTGGCCCTCTAT-3' (downstream), corresponding to nucleotides 2158-2178 and 2616-2635 of hGR $\alpha$ complementary DNA (cDNA) (Oakley et al., 1996). The primers used for amplification of $\beta$-actin were as follows: sense 5'-TGACGGGGTCACCCACACTGTGCCCAT-3', antisense 5'-GAAGCATTTGCGGTGGACGATGGAGGG-3'. Polymerase chain reaction (PCR) was performed with $2 \mu$ land $4 \mu$ of $\mathrm{RT}$ reaction mixture to analyze $\beta$-actin and $\mathrm{hGR} \alpha$ mRNA levels, respectively. The reactions contained $0.5 \mathrm{U}$ Taq DNA polymerase, $0.2 \mu \mathrm{M}$ of each oligonucleotide primer, $0.2 \mathrm{mM}$ deoxynucleotide mixture, $50 \mathrm{mM} \mathrm{KCl}, 10 \mathrm{mM}$ Tris- $\mathrm{HCl} \mathrm{pH} 8.3,2 \mathrm{mM} \mathrm{MgCl}_{2}$ in a final volume of $20 \mu \mathrm{l}$. PCR conditions were 30 cycles of $30 \mathrm{~s}$ at $95^{\circ} \mathrm{C}, 30 \mathrm{~s}$ at $63^{\circ} \mathrm{C}$, and $30 \mathrm{~s}$ at $72^{\circ} \mathrm{C}$. These were followed by a final extension step at $72^{\circ} \mathrm{C}$ for $10 \mathrm{~min}$. Amplified DNA fragments were electrophoretically separated on $1.7 \%$ agarose gels containing $0.5 \mu \mathrm{g} / \mathrm{ml}$ ethidium bromide and visualized under UV light. $\mathrm{hGR} \alpha$ and $\beta$-actin PCR products were semiquantified by densitometric scanning using a image report system Fluorochem 5500 (Core Biosystem, Korea) equipped with image analysis software. Amount of amplified hGR $\alpha$ cDNA was normalized to that of $\beta$-actin.

\section{Nested PCR}

Nested PCR was used to amplify hGR $\beta$ due to rare amount of hGR $\beta$ mRNA template. The first round of PCR was performed using $2 \mu$ of the cDNA from the reverse transcription. The primers used for the first round were as follows (Figure 1): 5'-CCTAAGGACGGTCTGAAGAGC-3' (upstream) and 5'-CCACGTATCCTAAAAGGGCAC-3' (downstream), corresponding to nucleotides 2158 to 2178 and 2503 to 2523 of hGR $\beta$ cDNA (Oakley et al., 1996). The PCR mixture contained $0.2 \mu \mathrm{M}$ of each outer primer or $0.2 \mu \mathrm{M}$ of the $\beta$-actin primers, together with the same reagents as described above. PCR conditions were 40 (hGR $\beta$ ) or 30 ( $\beta$-actin) cycles of $30 \mathrm{~s}$ at $95^{\circ} \mathrm{C}, 30 \mathrm{~s}$ at $54^{\circ} \mathrm{C}$ (hGR $\beta$ ) or $63^{\circ} \mathrm{C}$ ( $\beta$-actin), and $30 \mathrm{~s}$ at $72^{\circ} \mathrm{C}$. These were followed by a final extension step at $72^{\circ} \mathrm{C}$ for $10 \mathrm{~min}$.

Nested PCR was initiated with $4 \mu$ of the firstround PCR products of hGR $\beta$ cDNA amplification. The primers were used as follows: 5'-AGCACATCTCACACATTAAT-3' (upstream) and 5'-TATAGTTGTCGATGAGCATC-3' (downstream), corresponding to nucleotides 2338 to 2357 and 2455 to 2471 of hGR $\beta$ cDNA (Gagliardo et al., 2000). The PCR mixture was as described above. PCR reaction was per- formed by 30 cycles of $30 \mathrm{~s}$ at $95^{\circ} \mathrm{C}, 30 \mathrm{~s}$ at $54^{\circ} \mathrm{C}$, and $30 \mathrm{~s}$ at $72^{\circ} \mathrm{C}$. These were followed by a final extension step at $72^{\circ} \mathrm{C}$ for $10 \mathrm{~min}$. Amplified DNA fragments were analyzed as above. Quantities of hGR $\beta$ product from the nested PCR and of $\beta$-actin product from the first round of PCR were estimated by densitometric scanning. Amount of hGR $\beta$ cDNA amplified was normalized to that of $\beta$-actin.

\section{Statistical analysis}

Nonparametric tests were used to analyze the data. The Wilcoxon-Mann-Whitney test was used for paired comparisons of each test group with a respect to hGR mRNA expression levels. Statistical significance was set at $P<0.05$.

\section{Results and Discussion}

\section{Quantitative RT-PCR analysis of the hGR messages in nasal tissues}

To accurately assess the relative levels of the $\mathrm{hGR} \alpha$ and hGR $\beta$ mRNA transcripts, we performed quantitative RT-PCR on RNA present in nasal tissues isolated from subjects who have nasal polyp. Figure $2 \mathrm{~A}$ shows reaction cycle intensity curves for the 478-bp hGR $\alpha$ PCR product and 134-bp hGR $\beta$ PCR product that was obtained by a second round of nested PCR with the template amplified at a first PCR amplification of 40 cycles. 30 and 40 cycles of PCR amplifications that do not reach to the saturation of the PCR product was chosen to be appropriate to compare the expression level of hGR $\alpha$ and hGR $\beta$ mRNA, respectively (arrows in Figure 2A). At a first round of PCR, the presence of hGR $\beta$ cDNA of estimated length of 366 bps was not able to be detected because of rare abundance of the hGR $\beta$ message (data now shown). Thus, the hGR $\beta$ cDNA was reamplified with an additional round of PCR (nested PCR). Using the amplified hGR $\beta$ cDNA at a first round of RT-PCR as template, the hGR $\beta$ cDNA was amplified again with an additional 40 cycles of nested PCR. Expression of the housekeeping gene $\beta$-actin was also determined to provide an internal control for RT and PCR efficiencies. In order to assess basal expression level of hGR mRNAs in normal nasal tissues, the same RT-PCR for hGR mRNAs was also performed with nasal tissues of normal subjects. Figure 2B shows a representative electrophoretic analysis of the PCR products of hGR mRNAs obtained from the each patient group as well as the normal subject group. cDNA of $478 \mathrm{bp}$ length that was reverse transcribed against $h \mathrm{hR} \alpha \mathrm{mRNA}$ and the internal control cDNA (661 bps) synthesized from $\beta$-actin 
A

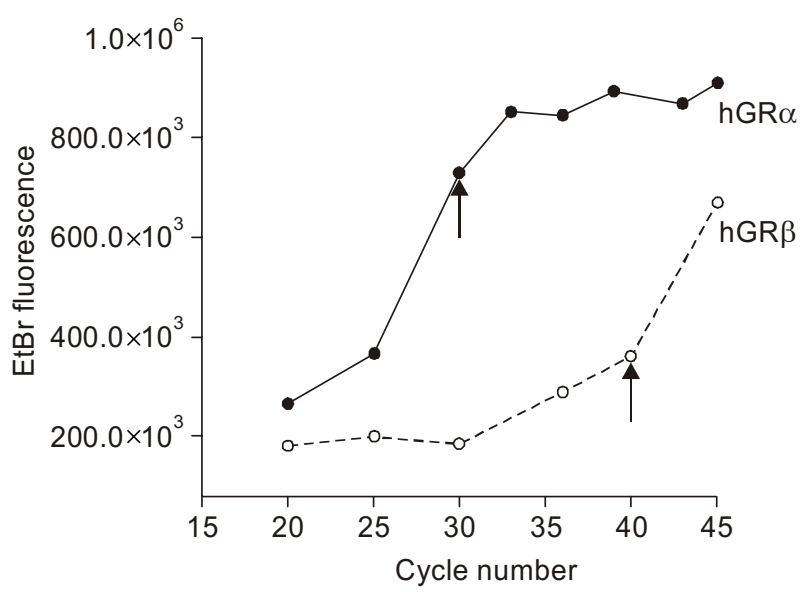

B
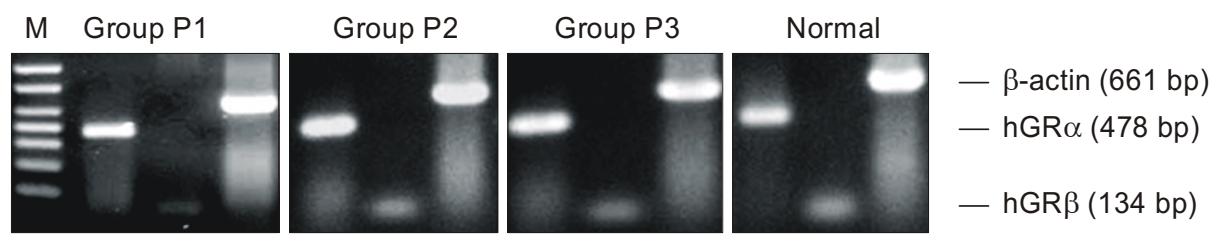

Figure 2. Quantitative RT-PCR analysis of $h G R \alpha$ and $h G R \beta$ messages. (A) RNA derived from nasal tissue of group P1 was reverse transcribed, and the resulting CDNA amplified using hGR $\alpha$ - or hGR $\beta$-specific primers. Aliquots of the PCR reaction was removed at 5-cycle intervals and electrophoresed on agarose gels stained with ethidium bromide. Note that RT-PCR product for hGR $\beta$ cDNA was the nested PCR products for hGR $\beta$ cDNAs; cDNA products obtained at the first round was reamplified with $h G R \beta$-specific cDNA primers. Arrow indicates the cycle number of PCR that was used for quantification of the PCR product in agarose gel electrophoresis as shown in (B). (B) Representative results of RT-PCR for $h G R \alpha$, hGR $\beta$, and $\beta$-actin mRNAs in nasal tissues derived from patient groups and normal subjects. The RT-PCR products were analyzed by $1.7 \%$ agarose gel electrophoresis. Lane M denotes molecular weight markers for DNA, 1000 bp, 800 bp, 600, bp, 500 bp, $400 \mathrm{bp}, 300 \mathrm{bp}$, and $200 \mathrm{bp}$ (top to bottom).

mRNA were detected in each tissue sample. We have also detected PCR product of hGR $\beta$ CDNA of 134 bps after the nested PCR (Figure 2B). All of groups have shown that detection of hGR $\beta$ cDNA requires the use of nested $P C R$, indicating that hGR $\alpha$ mRNA level is largely predominant over hGR $\beta$ mRNA in nasal tissues irrespective of the presence of inflammatory polyp. Thus, we report herein that $h G R \alpha$ mRNA was more expressed than the hGR $\beta$ mRNA in the nasal tissues regardless of polyp or GC treatment because $h G R \alpha$ was revealed by a simple PCR whereas detection of hGR $\beta$ required nested PCR.

It has been hypothesized that hGR $\beta$ has to be more abundant than $h G R \alpha$ to inhibit $h G R \alpha$-mediated gene regulation, but conflicting data concerning the relative levels of the two isoforms have been reported. In one study conducted with various human tissues and HeLa cells, the amount of hGR $\beta$ was found to be equal or higher than that of $h \mathrm{GR} \alpha$ (Castro et al., 1996). In contrast, other studies have shown that level of hGR $\beta$ was relatively lower than hGR $\alpha$ in HeLa cells and human lymphocytes (Bamberger et al., 1997; Hecht et al., 1997). In agreement with those latter results, our result demonstrates that hGR $\beta$ mRNA was less expressed than that of hGR $\alpha$ in the nasal tissues, which is regardless of GC efficacy or inflammation. Moreover, our observation was consistent with previous reports, in which quantitative RT-PCR experiments have shown that the hGR $\beta$ mRNA was 200- to 500-fold less represented than the hGR $\alpha$ mRNA in all human tissues and cell lines (Oakley et al., 1996). Clinically, this observation was also observed in GC-dependent asthmatics by showing less expression of hGR $\beta$ mRNA and protein relative to those of $h G R \alpha$ (Gagliardo et al., 2000). 


\section{$\mathrm{hGR} \alpha \mathrm{mRNA}$ is more expressed in nasal polyps than normal nasal tissues}

To compare the expression level of hGR $\alpha$ in nasal polyps and normal nasal tissues, we measured expression level of $h G R \alpha$ mRNA and $\beta$-actin as internal control with RT-PCR. Electrophoretic analysis of the RT-PCR products of hGR $\alpha$ mRNAs was performed on RNAs obtained from three patient groups and the normal group. Patient group of P3, which had nasal polyp without GC treatment, was observed to have hGR $\alpha$ mRNA moderately expressed relative to $\beta$-actin control. Densitometric scanning of the RT-PCR product bands showed that estimation of expressed $h G R \alpha / \beta$-actin cDNA ratio was averaged to be 0.593 (Figure $3 A$ ). In contrast, normal nasal tissue without polyp (' $N$ ' in Figure $3 A$ ) expressed less amount of hGR $\alpha$ mRNA (average hGR $\alpha / \beta$-actin cDNA ratio of 0.245$)$ compared with P3 $(P<0.01)$. Thus, nasal tissues without inflammation maintained relatively less amount of $h \mathrm{GR} \alpha$ than the patient groups with nasal polyp. Interestingly, patient group P1 who were treated with GC and showed positive GC efficacy exhibited lower level of $h G R \alpha$ mRNA expression (average $h G R \alpha /$ $\beta$-actin cDNA ratio of 0.310 , Figure $3 A$ ) than the group of GC-untreated nasal polyp (P3) $(P<0.01)$, but is almost close to the level observed in the normal group.

Five patients with nasal polyp were treated with GC (Group P1), and their nasal tissues were obtained twice, before and after the medication. As shown in Figure 3B, hGR $\alpha$ mRNA expression was decreased after a GC treatment $(P<0.05)$, indicating that a short-course of GC treatment downregulated $\mathrm{hGR} \alpha$ in conjunction with anti-inflammation effect in nasal tissues. Thus, low level of hGRo expression in P1 was likely to be caused by GC administration to the patients. This observation was consistent with the previous report that $\mathrm{hGR} \alpha$ was downregulated after a short-course of oral GC treatment of asthmatics (Gagliardo et al., 2000). GC treatment elicited anti-inflammation effect as well as a decrease of $\mathrm{hGR} \alpha$ expression in those asthma patients. This result was partly explained by earlier study with COS1 cells, in which hGR cDNA can downregulate the induction of hGR gene (Burnstein et al., 1990). Thus, increased level of hGR $\alpha$ mRNA in nasal polyp could subsequently be reduced after GC treatment as observed in our study (group P1). Previous studies have suggested that the transcription factor nuclear factor kappa $B(N F-\kappa B)$ plays an important role in the induction of various proinflammatory cytokines (Schreck et al., 1990; Mukaida et al., 1994). These proinflammtory cytokines have been shown to upregulate hGR gene expression (Webster et al., 2001). Hence, we suggest that high level of NF- $\mathrm{KB}$ expression in inflamed tissue activates proiflammatory cytokines, which in turn induce expression of hGR gene. Therefore, relatively low level of $h G R \alpha$ mRNA expression in P1 and normal
A

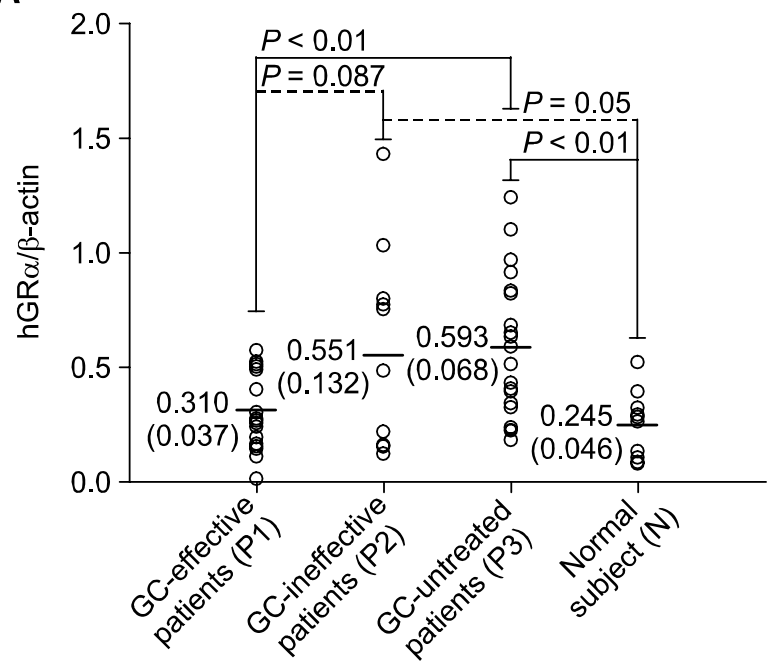

B

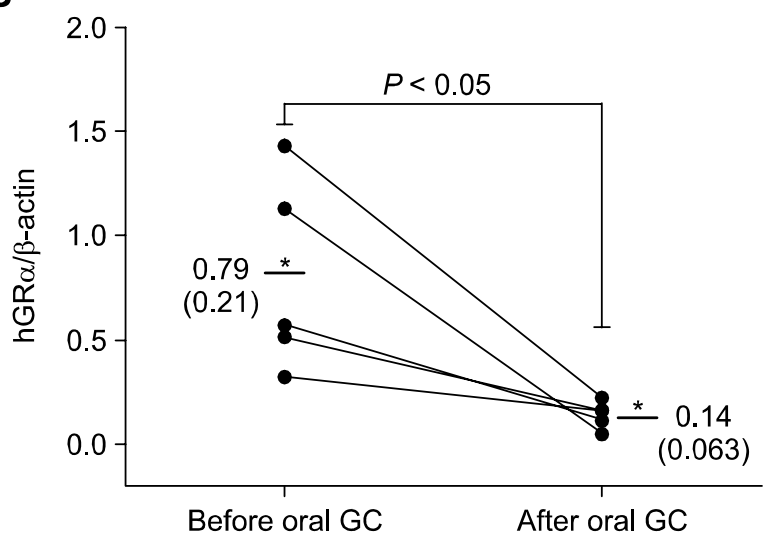

Figure 3. Comparison of hGR $\alpha$ expression in nasal tissues from various groups. (A) RT-PCR products for hGR $\alpha$ mRNA was semiquantified by densitometric scanning and normalized relative to the amount of $\beta$-actin. Result of each subject was expressed as spot and the average of the values in each group was indicated as horizontal bar in the middle of graph with a standard error in parenthesis. Statistical analysis for correlation was performed and represented in the graph. (B) Effect of GC-treatment on hGR $\alpha$ expression. Expression of hGR $\alpha$ mRNA in 5 patients was monitored before and after an oral GC treatment (prednisolone at $20 \mathrm{mg} /$ daily for a week). Individual data are shown, and average was indicated with a horizontal bar with an asterisk (a standard error in parenthesis). 
group might be caused by the result of low level of the proinflammatory cytokines in nasal tissues. We are currently investigating this issue of whether an excess of NF-KB activity and increased level of proinflammatory cytokines are related with $\mathrm{hGR} \alpha$ expression in the tissue and cells.

We also compared $\mathrm{hGR} \alpha$ expression level of GC-resistant patients (P2, average hGR $\alpha / \beta$-actin cDNA ratio of 0.551 ) with other groups (Figure $3 A$ ). Compared with groups of $\mathrm{P} 1$ and $\mathrm{N}, \mathrm{hGR} \alpha \mathrm{mRNA}$ was relatively more expressed in group $\mathrm{P} 2(P=$ $0.05-0.09)$. This result indicates two points; (1) antiinflammation efficacy of $\mathrm{GC}$ and $\mathrm{hGR} \alpha$ expression level has no correlation during the $\mathrm{GC}$ treatment (P1 vs. P2), and (2) inflamed nasal tissues with GC-resistance express more hGR $\alpha$ mRNA than the normal or GC-effective nasal tissues (P2 vs. P1 or $N)$. Therefore, the incapacity of GC to inhibit inflammation in nasal tissue of the GC-resistant patients is not due to a low level of hGR $\alpha$.

\section{Inefficacy of GC treatment is not the result of overexpression of hGR $\beta$}

It has been proposed that elevated level of hGR $\beta$ might cause glucocorticoid resistance in patients by overriding hGR $\alpha$ activity (Oakley et al., 1996; 1999). This hypothesis on the inhibitory effect of hGR $\beta$ in hGR $\alpha$-mediated transcription has been tested in vitro with tissues obtained from corticoresistant asthmatics (Bamberger et al., 1995; Oakley et al., 1996). However, the hypothesis is still controversial with respect to putative role of hGR $\beta$ in inhibition of $h G R \alpha$ activity. Thus, to test this hypothesis in the nasal polyp tissue after GC treatment, we have analyzed the amount of hGR $\beta$ mRNA in each patient group. hGR $\beta$ mRNA expression in nasal tissues of three patient groups and normal subject was analyzed by agarose gel electrophoresis after a second round of PCR (Figure 2B). PCR products were semiquantified by densitometric scanning and amount of hGR $\beta$ mRNA was determined by the ratio of hGR $\beta$ cDNA relative to the amount of $\beta$-actin cDNA (hGR $\beta / \beta$-actin cDNA in Figure 4). Densitometric analysis of the data indicated that the amount of hGR $\beta$ was similar in normal subjects and in the three groups of nasal polyps (Figure 4) without a statistically significant difference $(P>0.05)$. Importantly, we observed that the expression of hGR $\beta$ was not related with GC- resistance because hGR $\beta$ mRNA expression in group $\mathrm{P} 1$ (average = 0.073 ) was statistically similar to that observed in group P2 (average $=0.103$ ). This finding indicates that incapacity of GC to inhibit inflammation in these patients (group P2) is not due to a high level of hGR $\beta$.

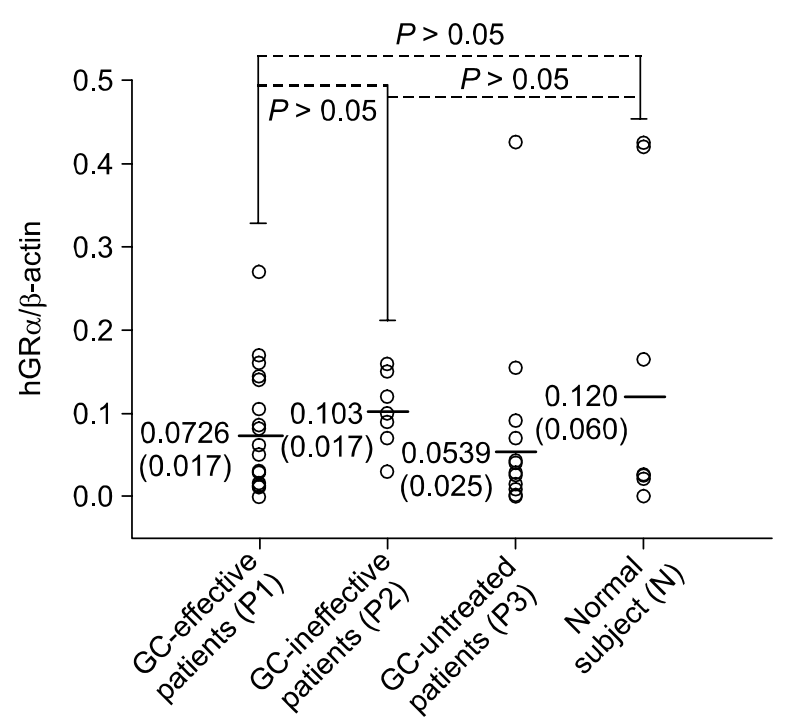

Figure 4. hGR $\beta$ mRNA expression in nasal tissues from various groups. Nested PCR products for hGR $\beta$ mRNA was semiquantified by densitometric scanning and normalized relative to the amount of $\beta$-actin. Result of each subject was expressed as spot and the average of the values in each group was indicated as horizontal bar in the middle of graph with a standard error in parenthesis. Any statistically significant difference between each group was not observed $(P>$ 0.05).

It has been reported that in asthma patients increased IL-4 production might cause GC-resistance by demonstrating a close relationship between GCresistance and IL-4 production, in which enhanced IL-4 production caused by DNA sequence variant was positively correlated with GC-resistance in asthmatic patients (Burchard et al., 1999; Rosenwasser et al., 2001). Thus, yet undefined factors in vivo are likely responsible for preventing activity of hGR $\alpha$ with glucocorticoid in those patients showing the GC-resistance. In conclusion, in nasal tissues with polyp the persistent GC-resistance and resulted inflammation despite GC treatment is not the result of low expression of $h \mathrm{GR} \alpha$ or overexpression of hGR $\beta$.

\section{Acknowledgment}

This work supported by the Dong-Eui University Research Grant (2005AA182) endowed to D-E Kim.

\section{References}

Bamberger CM, Bamberger AM, de Castro M, Chrousos GP. Glucocorticoid receptor beta, a potential endogenous inhibitor of glucocorticoid action in humans. J Clin Invest 1995;95: 2435-41

Bamberger CM, Else T, Bamberger AM, Beil FU, Schulte HM. 
Regulation of the human interleukin-2 gene by the alpha and beta isoforms of the glucocorticoid receptor. Mol Cell Endocrinol 1997;136:23-28

Brogan IJ, Murray IA, Cerillo G, Needham M, White A, Davis JR. Interaction of glucocorticoid receptor isoforms with transcription factors AP-1 and NF-kappaB: lack of effect of glucocorticoid receptor beta. Mol Cell Endocrinol 1999;157: 95-104

Burchard EG, Silverman EK, Rosenwasser LJ, Borish L, Yandava C, Pillari A, Weiss ST, Hasday J, Lilly CM, Ford JG, Drazen JM. Association between a sequence variant in the IL-4 gene promoter and FEV (I) in asthma. Am J Respir Crit Care Med 1999;160:919-22

Burnstein KL, Jewell CM, Cidlowski JA. Human glucocorticoid receptor cDNA contains sequences sufficient for receptor down-regulation. J Biol Chem 1990;265:7284-91

Cato A, Wade E. Molecular mechanisms of anti-inflammatory action of glucocorticoids. Bioessays 1996;18:371-8

de Castro M, Elliot S, Kino T, Bamberger C, Karl M, Webster $E$, Chrousos GP. The non-ligand binding beta-isoform of the human glucocorticoid receptor (hGR beta): tissue levels, mechanism of action, and potential physiologic role. Mol Med 1996;2:597-607

de Lange P, Koper JW, Brinkmann AO, de Jong FH, Lamberts SW. Natural variants of the beta isoform of the human glucocorticoid receptor do not alter sensitivity to glucocorticoids. Mol Cell Endocrinol 1999;153:163-8

Encio IJ, Detera-Wadleigh SD. The genomic structure of the human glucocorticoid receptor. J Biol Chem 1991;266:7182-8

Gagliardo R, Chanez P, Vignola AM, Bousquet J, Vachier I, Godard P, Bonsignore G, Demoly P, Mathieu M. Glucocorticoid receptor alpha and beta in glucocorticoid dependent asthma. Am J Respir Crit Care Med 2000;162:7-13

Hecht K, Carlstedt-Duke J, Stierna P, Gustafsson J, Bronnegard M, Wikstrom AC. Evidence that the beta-isoform of the human glucocorticoid receptor does not act as a physiologically significant repressor. J Biol Chem 1997;272: 26659-64

Hollenberg SM, Weinberger C, Ong ES, Cerelli G, Oro A, Lebo $R$, Thompson EB, Rosenfeld MG, Evans RM. Primary structure and expression of a functional human glucocorticoid receptor cDNA. Nature 1985;318:635-41

Kang JM, Cho JH, Won YS, Kim SS, Cgang HS, Yonn HR. Expression of glucocorticoid receptor in nasal polyps and nasal mucosa. Korean J Otolaryngol 2000;43:731-6

Leung DY, Hamid Q, Vottero A, Szefler SJ, Surs W, Minshall
E, Chrousos GP, Klemm DJ. Association of glucocorticoid insensitivity with increased expression of glucocorticoid receptor beta. J Exp Med 1997;186:1567-74

Leung DY, Bloom JW. Update on glucocorticoid action and resistance. J Allergy Clin Immunol 2003;111:3-22

Mukaida N, Morita M, Ishikawa Y, Rice N, Okamoto S, Kasahara T, Matsushima K. Novel mechanism of glucocorticoid-mediated gene repression. Nuclear factor-kappa B is target for glucocorticoid-mediated interleukin 8 gene repression. J Biol Chem 1994;269:13289-95

Oakley RH, Sar M, Cidlowski JA. The human glucocorticoid receptor beta isoform. Expression, biochemical properties, and putative function. J Biol Chem 1996;271:9550-9

Oakley RH, Jewell CM, Yudt MR, Bofetiado DM, Cidlowski JA. The dominant negative activity of the human glucocorticoid receptor beta isoform. Specificity and mechanisms of action. J Biol Chem 1999;274:27857-66

Oettagen HC, Geha RS. IgE regulation and roles in asthma pathogenesis. J Allergy Clin Immunol 2001;107:429-40

Pratt WB. The role of heat shock proteins in regulating the function, folding, and trafficking of the glucocorticoid receptor. J Biol Chem 1993;268:21455-8

Rosenwasser L, Klemm JD, Klemm DJ, Drazen JM, Burchard $E G$, Leung DYM. Association of asthmatic steroid insensitivity with an IL-4 gene promoter polymorphism. J Allergy Clin Immunol 2001;107:S235

Ruiz-Irastorza G, Khamashta MA, Castellino G, Hughes GR. Systemic lupus erythematosus. Lancet 2001;357:1027-32

Schreck R, Baeuerle PA. NF-kappa B as inducible transcriptional activator of the granulocyte-macrophage colonystimulating factor gene. Mol Cell Biol 1990;10:1281-6

Sher ER, Leung DY, Surs W, Kam JC, Zieg G, Kamada AK, Szefler SJ. Steroid-resistant asthma. Cellular mechanisms contributing to inadequate response to glucocorticoid therapy. $\mathrm{J}$ Clin Invest 1994;93:33-9

Smith DF, Toft DO. Steroid receptors and their associated proteins. Mol Endocrinol 1993;7:4-11

Webster JC, Oakley RH, Jewell CM, Cidlowski JA. Proinflammatory cytokines regulate human glucocorticoid receptor gene expression and lead to the accumulation of the dominant negative beta isoform: a mechanism for the generation of glucocorticoid resistance. Proc Natl Acad Sci USA 2001;98: 6865-70

Wills-Karp M. IL-12/IL-13 axis in allergic asthma. J Allergy Clin Immunol 2001;107:9-18 